Pesq. Vet. Bras. 36(9):819-825, setembro 2016 DOI:10.1590/S0100-736X2016000900005

\title{
Characterization of an IgM-like immunoglobulin from silver catfish (Rhamdia quelen) serum and its use for the production of polyclonal antibodies and development of immunoassays $^{1}$
}

\author{
Luiz C. Kreutz ${ }^{2 *}$, Raíssa Canova ${ }^{3}$, Cristian O. Nied ${ }^{4}$, Márcia Bortoluzzi ${ }^{5}$ \\ and Rafael Frandoloso ${ }^{2}$
}

\begin{abstract}
Kreutz L.C., Canova R., Nied C.O., Bortoluzzi M. \& Frandoloso R. 2016. Characterization of an IgM-like immunoglobulin from silver catfish (Rhamdia quelen) serum and its use for the production of polyclonal antibodies and development of immunoassays. Pesquisa Veterinária Brasileira 36(9):819-825. Universidade de Passo Fundo, Campus I, Bairro São José, BR-282 Km 171, Passo Fundo, RS 99052-900, Brazil. E-mail: lckreutz@upf.br

Knowledge on fish immunoglobulin (Ig) characteristics and the availability of monoclonal or polyclonal antibodies to fish Igs are essential to evaluate the humoral immune response and the Ig distribution on leukocyte cells. We demonstrated that silver catfish serum Ig is composed of one immunodominant $\mathrm{H}$ chain with approximately $75 \mathrm{k}$ Da and one L chain with approximately $28 \mathrm{kDa}$, similar to human IgM. Rabbit polyclonal antibodies to the catfish IgM-like Ig recognized both the $\mathrm{H}$ and $\mathrm{L}$ chain and were useful in developing an indirect ELISA to measure the production of antibodies in fish immunized with bovine serum albumin. Dot blot and western blot cross-reactivity studies indicated a wide degree of epitope sharing amongst Ig from several Siluriformes and Characiformes fish indigenous to Brazilian rivers. In these fish species, polyclonal antibodies reacted mostly with the $\mathrm{H}$ chain. The results presented here are central to the development of tools and strategies to investigate the antibody production to inoculated antigens and tissue distribution of Ig molecules in native fish species. Furthermore, because of the wide range of cross-reactivity, polyclonal antibodies to silver catfish IgM-like Ig might be used to develop immunoassays to measure the humoral immune response in other fish species.
\end{abstract}

INDEX TERMS: IgM, antibody production, silver catfish, Rhamdia quelen, polyclonal antibodies, immunoassay.

RESUMO.- [Caracterização de imunoglobulina similar a IgM em soros de jundiás (Rhamdia quelen) e sua utilização para a produção de soro policlonal e desen-

\footnotetext{
${ }^{1}$ Received on February 15, 2016.

Accepted for publication on June 20, 2016.

${ }^{2}$ Laboratório de Microbiologia e Imunologia Aplicada, Programa de Pós-Graduação em Bioexperimentação, Universidade de Passo Fundo (UPF), Campus I, Bairro São José, BR-282 Km 171, Passo Fundo, RS 99052-900, Brazil. *Corresponding author: lckreutz@upf.br

${ }^{3}$ Médica Veterinária, Mestranda do Programa de Pós-Graduação em Bioexperimentação, UPF, Campus I, Bairro São José, BR-282 Km 171, Passo Fundo, RS 99052-900, Brazil.

${ }^{4}$ Graduando do Curso de Medicina Veterinária, UPF, Campus I, Bairro São José, BR-282 Km 171, Passo Fundo, RS 99052-900, Brazil. Bolsista Pibic/CNPq.

${ }^{5}$ Curso de Ciências Biológicas, UPF, Campus I, Bairro São José, BR-282 Km 171, Passo Fundo, RS 99052-900, Brazil. Bolsista FAPERGS.
}

volvimento de imunoensaios.] Informações sobre as características das imunoglobulinas (Ig) de peixes e a disponibilidade de anticorpos mono ou policlonais são essenciais para avaliar a resposta imune humoral e a distribuição leucocitária de Igs. Nesse trabalho nós demonstramos que a Ig do soro de jundiás é composta por uma cadeia pesada $(\mathrm{H})$ imunodominante, de aproximadamente $75 \mathrm{kDA}$ e de uma cadeia leve (L) de aproximadamente $28 \mathrm{kDa}$, similar à IgM humana. Anticorpos policlonais produzidos contra a Ig do jundiá reconheceram a cadeia $\mathrm{H}$ e L e permitiram o desenvolvimento de um ELISA indireto para mensurar a produção de anticorpos em peixes imunizados com albumina sérica bovina. Estudos de reatividade cruzada, por meio de Dot blot e western blot, indicaram um alto grau de compartilhamento de epitopos entre as Igs de diversos pei- 
xes Siluriformes e Caraciformes nativos do Brazil. Nestas espécies de peixes, os anticorpos policlonais reconheceram principalmente a cadeia H. Os resultados deste estudo são fundamentais para o desenvolvimento de ferramentas e estratégias para investigar a produção de anticorpos subsequente à imunização e a distribuição tecidual de Igs em peixes nativos. Além disso, devido ao compartilhamento de epitopos entre as espécies de peixes avaliadas, os anticorpos policlonais anti Ig do jundiá poderão ser usados para desenvolver ensaios imunoenzimáticos para avaliar a resposta imune humoral nestas espécies.

TERMOS DE INDEXAÇÃO: IgM, jundiá, Rhamdia quelen, produção anticorpos, produção de anticorpos, ensaio imunoenzimático.

\section{INTRODUCTION}

Silver catfish (Rhamdia quelen) is an indigenous species endemic to South American rivers and lakes and considered a good candidate for intensive husbandry in neotropical and temperate climates (Schulz \& Leuchtenberger 2006) either alone or commingled with other fish species (Da Silva et al. 2008). However, the continuous growth of fish husbandry and intensive production systems comes along with new challenges like outbreaks of infectious diseases and the need to monitor exposure to microorganism (Secombes 2008). In this scenario, knowledge of effective defense mechanisms and developing immunobiological reagents for immunoassays are much needed.

The innate immune system and corresponding components are essential for pathogen recognition and to trigger cells responsible for acquired immunity (Magnadóttir 2006, Iwasaki \& Medzhitov 2010). Although innate immune mechanisms mediate first line of defense, elimination of infecting microorganism relies on a robust response of cells, e.g. lymphocytes, and the production of antigen-specific Ig which are major components of the acquired immune response (Magnadottir et al. 2005). In teleost fish, a single tetrameric Ig similar to mammalian IgM (IgM-like) has been described as the predominant Ig isotype (Fillatreau et al. 2013) found soluble in serum or as a lymphocyte membrane bound molecule. In addition, chimeric Ig genes with similarity to other mammalian isotypes, namely IgD and IgT/IgZ, have already been found in a few fish species (Zhang et al. 2011, Fillatreau et al. 2013, Sunyer 2013). Although recent reports point out for a possible involvement in mucosal immunity (Zhang et al. 2010, Salinas et al. 2011), the role of these isotypes in protection is still a matter of debate.

In recent years, knowledge on fish immune system has benefited from the characterization of Ig and Ig-bearing cells. Polyclonal and monoclonal antibodies to fish Ig have been crucial for developing immunological tools to evaluate total and specific concentrations of serum antibodies produced in response to inoculated antigen and to monitor the occurrence and prevalence of pathogenic microorganisms (Crosbie \& Nowak 2002, Beelen et al. 2004, Grove et al. 2006b, Li et al. 2007, Rathore et al. 2008, Suresh Babu et al. 2008, Lim et al. 2009, Santos et al. 2009, Sood et al. 2011, Boardman et al. 2012, Hedfors et al. 2012, Purcell et al. 2012). Anti-immunoglobulin antibodies have also been used to characterize and study the ontogeny and tissue distribution of cells subsets bearing membrane bound Ig (Beelen et al. 2004, Grove et al. 2006a, Tian et al. 2009) and in cross reactivity studies to gain information on phylogenetic relationship amongst different species (Swennes et al. 2007, Rathore et al. 2008, Bag et al. 2009, Santos et al. 2009). Studies on silver catfish Ig and reacting anti-Ig antibodies have not been reported yet and the lack of relevant reagents for immunological studies hampers further studies on this fish species, mainly those concerning the evaluation of the humoral immune response following immunization, and the functional characterization of Ig-bearing subsets of leukocytes.

Here, our main goals were to isolate and characterize the major serum Ig of silver catfish and to produce and test the use of anti-Ig polyclonal antibodies in immunological assays and their reactivity with serum Ig from other fish species.

\section{MATERIALS AND METHODS}

Purification and analysis of silver catfish Ig. Two different strategies were applied to isolate silver catfish serum Ig. First, blood samples from five adult healthy silver catfish were collected from the caudal vein, pooled and allowed to clot overnight $\left(4^{\circ} \mathrm{C}\right)$. Serum was separated by centrifugation at $1000 \mathrm{~g}$ for $20 \mathrm{~min}$ and stored at $-20^{\circ} \mathrm{C}$ until use. Igs were purified from serum using MBP affinity columns (ImmunoPure-IgM, Pierce, Rockford, Il) following manufactures instruction. Second, five adult healthy silver catfish were immunized with bovine serum albumin (BSA, 200 $\mu \mathrm{g} /$ fish) mixed to Freund's complete adjuvant (FCA, 1:1.2 ratio) and boosted at 21 and 42 days with BSA $(200 \mu \mathrm{g} /$ fish) mixed to Freund incomplete adjuvant (FIA), at the same ratio. Blood was collected from the caudal vein 14 days after the last boosting injection and processed as indicated above. Anti-BSA fish Ig was purified by an immunoaffinity chromatography column $(5 \mathrm{ml})$ containing BSA cross-linked to CNBr-Activated Sepharose 4B (GE Healthcare), prepared according to the manufacturer's instructions. Silver catfish serum was diluted 10 times with binding buffer $(20 \mathrm{mM}$ sodium phosphate, pH 7.0$)$, filtered $(0.22 \mu \mathrm{m})$ and then applied by gravity into the BSA-column, previously equilibrated with the same buffer. The column was incubated in an orbital shaker for $2 \mathrm{~h}$ at room temperature. Non-binding immunoglobulins were washed out with 10 columns volumes of binding buffer. Anti-BSA Ig was eluted with $10 \mathrm{ml}$ of elution buffer ( $0.1 \mathrm{M}$ glycine- $\mathrm{HCl}, \mathrm{pH} 2.7)$. Fractions $(1 \mathrm{ml})$ were collected and immediately neutralized with $60 \mu \mathrm{l}$ of neutralizing buffer ( $1 \mathrm{M}$ Tris- $\mathrm{HCl}, \mathrm{pH} 9.0$ ). In both metho$\mathrm{ds}$, the protein concentration of eluted fractions was determined by the Bradford method (Bradford 1976). Purified Ig was dialyzed on PBS ( $\mathrm{pH} 7.2$ ) at $4^{\circ} \mathrm{C}$, concentrated (Amicon Ultra-10 K, Millipore) and stored at $-20^{\circ} \mathrm{C}$.

Sodium dodecyl sulfate polyacrylamide gel electrophoresis (SDS-PAGE). Aliquots eluted from both affinity columns were analyzed by standard SDS-PAGE under reducing conditions using $5 \%$ acrylamide stacking gel overlaid on $10 \%$ acrylamide resolving gel. Human IgM (Sigma) was loaded onto the gel for comparison purposes. Gels were stained by Coomassie blue R-250 and the proteins obtained compared to purified human IgM (Sigma) and molecular weight markers (Amresco).

Rabbit immunization with silver catfish serum Ig. Three New Zealand rabbits were primed by subcutaneous injection of the putative silver catfish $\mathrm{Ig}(100 \mu \mathrm{g} / \mathrm{rabbit})$ emulsified in FCA (ratio 1:1.2). The inoculum $(1.0 \mathrm{ml})$ was equally distributed in 8 to 10 injection sites. Boosting immunizations were carried out with the same amount of antigen emulsified in FIA at 14 and 28 days following priming. Blood samples were collected from the rabbits prior to inoculation and at the time of antigen injections 
to monitor the production of specific antibodies. Final bleeding was performed by cardiac puncture 14 days after the last immunization.

Fish immunization with BSA. Thirty silver catfish (80 to $100 \mathrm{~g}$ ) of both sexes were acclimatized in two self-cleaning tanks containing $1000 \mathrm{~L}$ of continuously running water (15 fish/tank). Fish from each tank were then immunized by intraperitoneal injection of BSA $(200 \mu \mathrm{g} / \mathrm{fish})$ emulsified in FCA (1:1.2 ratio), or with BSA mixed with phosphate buffered saline (PBS, pH 7.2). Blood samples were collected from the caudal vein prior to (day 0 ) and at 14, 28 and 42 days after immunization to monitor the presence of antibodies to BSA. These blood samples and the rabbit polyclonal serum to the IgM-like Ig were used to develop an enzyme-linked immunosorbent assay (ELISA) to measure silver catfish humoral response. Water parameters were measured throughout the experiment and found within the expected range (dissolved oxygen was $5.2 \pm 0.4$; pH ranged from 7.0 to 7.2 ; water hardness and alkalinity were both $45 \pm 5 \mathrm{mg} \mathrm{CaCO}_{3} / \mathrm{L}$ and total ammonia was below $0.6 \mathrm{mg} / \mathrm{L}$. Fish were fed twice daily with commercial fish pellets ( $42 \%$ crude protein, Supra, Brazil).

Dot blot immunoassay. Bovine serum albumin ( $8 \mathrm{ug}$ ) was dropped to nitrocellulose membrane strips and used to react with serum from fish immunized with BSA. Nitrocellulose membranes were blocked with phosphate buffered saline (PBS, pH 7.4) containing $0.05 \%$ Tween-20 (PBS-T) and 3\% skim milk (PBS-TSK) for $1 \mathrm{~h}$ with constant shaking and then allowed to react for $1 \mathrm{~h}$ with serum from fish immunized with BSA, diluted 1:100 in PBS-T 1\% SK. Membranes were washed three times, 10 min each with PBST and incubated with rabbit hyperimmune serum diluted 1:200 in PBST, for $1 \mathrm{~h}$. Membranes were washed again and incubated with goat anti-rabbit peroxidase conjugated (1:1000 in PBS-T 1\% SK, $1 \mathrm{~h})$. After washing, membranes were incubated with peroxidase substrate $(60 \mathrm{mg}$ of 4-chloro-1-naphtol $+20 \mathrm{ml}$ of cold methanol) mixed to PBS $(100 \mathrm{ml})$ containing hydrogen peroxide $(0.018 \%)$. The reaction was stopped by rinsing the membrane with distilled water. Serum from non-immunized fish and non-immunized rabbits were also included as negative controls.

After ascertain that rabbit polyclonal antibodies were directed to silver catfish IgM-like, the heterologous reactivity of the polyclonal antibodies was tested with serum from several fish species, as indicated in the figure legend. In this assay, total protein content of each fish serum was adjusted to $5 \mathrm{mg} / \mathrm{ml}$ and $2 \mu \mathrm{l}$ was spotted in nitrocellulose membrane strips, followed by incubation with rabbit polyclonal antibodies and goat anti-rabbit conjugate as indicated above.

Western Blot to silver catfish IgM-like. After SDS-PAGE, silver catfish purified Igs were transferred to nitrocellulose membranes $(0.45 \mu \mathrm{M})$ using a semi-dry apparatus by standard protocols. Nitrocellulose membranes were blocked with phosphate buffered saline (PBS, pH 7.4) containing 0.05\% Tween-20 (PBS-T) and $3 \%$ skim milk (PBS-TSK) for $1 \mathrm{~h}$ with constant shaking and then allowed to react with rabbit hiperimmune serum $1: 100$ in PBS-T 1\% SK, 1h) followed by three washes of 10 min each with PBST and incubated with goat anti-rabbit peroxidase conjugated (1:1000 in PBS-T 1\% SK, 1h). The reaction was then developed as indicated above for dot-blot.

Enzyme-linked immunosorbent assay. The reactivity and potential use of rabbit anti-catfish Ig for diagnosis was evaluated by indirect ELISA using serum collected prior to and at 14, 28 and 42 days after immunizing fish with BSA. The concentration of antigen and antibodies were optimized by preliminary assays using a checkerboard method. Flat bottom 96-well plates were coated with BSA (5ug/well) diluted in carbonate-bicarbonate buffer (150mM Na $\left.\mathrm{CO}_{3}, 348 \mathrm{mM} \mathrm{NaHCO}, 30 \mathrm{mM} \mathrm{NaN}_{3}, \mathrm{pH} 9.6\right)$ and incubated at $4{ }^{\circ} \mathrm{C}$ overnight. PBS-T 3\% SK was used to block empty space on the wells. Fish serum was diluted 1:100; rabbit polyclonal antiserum was diluted 1:1000, and goat anti-rabbit peroxidase labeled was diluted 1:20.000. Antibodies were diluted in PBS-T 1\%SK and allowed to bind for $60 \mathrm{~min}$ at room temperature. Four washes were performed with PBST to remove unbound antibodies. The reaction was developed using ortho-phenylenediamine (OPD; $1 \mathrm{mg} / \mathrm{ml}$, Sigma) containing hydrogen peroxide $(0.002 \%)$ for $15 \mathrm{~min}$ in the dark. The reaction was stopped by adding an equal volume of $2 \mathrm{~N} \mathrm{H}_{2} \mathrm{SO}_{4}$. Color development was measured at $492 \mathrm{~nm}$. Negative controls were always included and consisted of serum from non-immunized fish and, in different wells, rabbit serum harvested prior to immunization with fish Ig.

Ethical approval. All applicable national, and/or institutional guidelines for the care and use of animals were followed. The experimental design was approved by a Committee of welfare and ethical use of animals.

\section{RESULTS \\ Purification of silver catfish serum Ig}

Aliquots eluted from both columns had the protein content determined by the Bradford method (results not shown) and analyzed by standard SDS-PAGE. Two main proteins of approximately $75 \mathrm{kDa}$ and $28 \mathrm{kDa}$, similar in size to the heavy $(\mathrm{H})$ and light $(\mathrm{L})$ chain of human IgM, were observed in several fractions (Fig.1A). Additional proteins slightly smaller than the putative $\mathrm{H}$ chain (not shown) were observed in aliquots eluted from the BSA affinity column. Aliquots containing the putative $\mathrm{H}$ and $\mathrm{L}$ chain were pooled, concentrated and stored at $-20^{\circ} \mathrm{C}$ for rabbit inoculation. Western blot analysis with rabbit polyclonal antiserum demonstrated reactivity with the purified protein and proteins of similar size from whole silver catfish serum (Fig.1B).

\section{Specificity of rabbit polyclonal antiserum to silver ca- tfish IgM-like Ig}

Rabbits immunized with silver catfish IgM-like Ig produced a strong immune response, as detected by a dot-blot assay (data not shown). The identity of the Ig isolated from silver catfish, and the specificity of rabbit polyclonal antibodies, were ascertain by a dot blot using serum from fish immunized with BSA (Fig.2). Here, rabbit polyclonal antibody specifically detected fish immunized with BSA (Fig. 2, column D and E) whereas no reaction was observed with serum from pre-immunized fish (Fig.2, column C), or rabbit serum collected prior to immunization with fish Ig (Fig.2, column B). In addition, no reactivity was observed when fish serum was not included in the assay (Fig.2, column A).

\section{Detection of fish anti-BSA antibodies by ELISA}

An indirect ELISA was standardized using serum collected from fish prior to and after immunization with BSA. Optical density (OD) obtained with pre-immunization serum (day 0) was similar to background levels. Anti-BSA antibodies were detected in both groups of fish at 14 days post immunization (Fig.3). At 28 and 42 days post immunization a significantly higher $(\mathrm{p}<0.001)$ anti-BSA antibodies titers was detected in fish immunized with BSA+FCA compared to fish immunized with BSA+PBS. In the BSA+FCA 

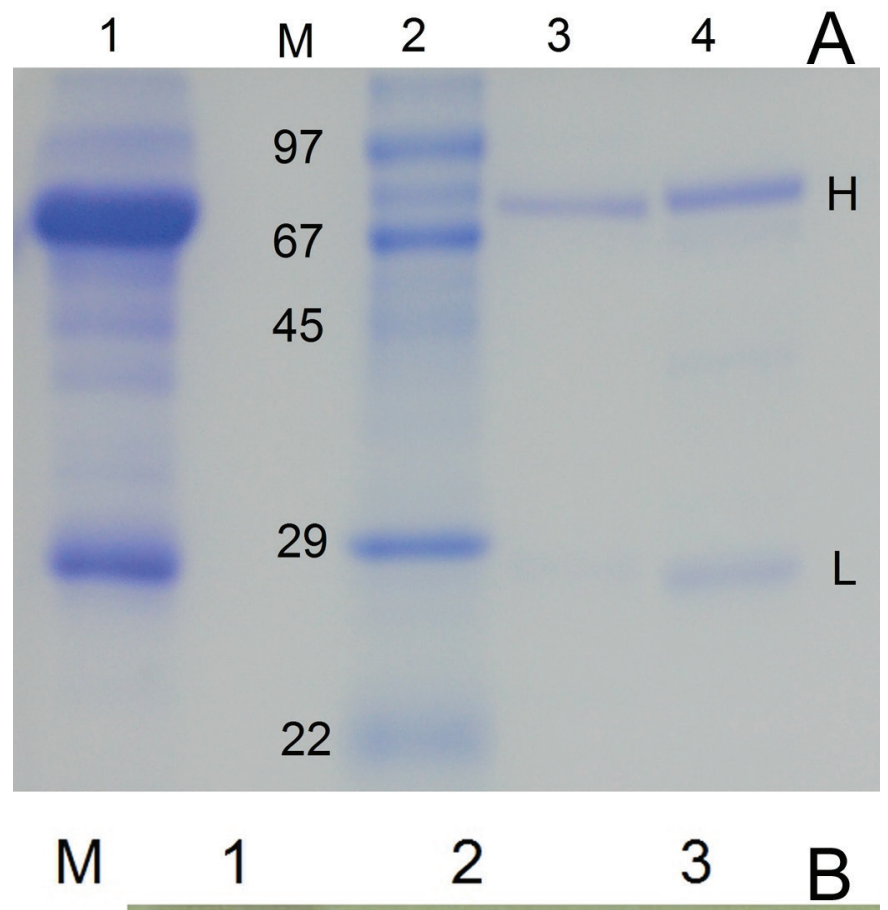

\section{5}

Fig.1. (A) Coomassie blue stained reduced SDS-PAGE analysis and (B) western blot detection of silver catfish IgM-like immunoglobulin. Panel A lane 1: whole silver catfish serum; lane M: size of molecular weight marker as indicated on lane 2; lane 3: purified silver catfish immunoglobulin; lane 4: human IgM. Panel B lane 1: whole silver catfish serum; lane 2 and 3 correspond to purified silver catfish purified immunoglobulin obtained from MBP and BSA affinity columns, respectively. M: position of molecular weight markers.

immunized group antibody titer peaked at 28 days decreasing slightly $(\mathrm{p}<0.05)$ at 42 days.

\section{Cross-reactivity of IgM-like antiserum to other fish Igs}

The cross-reactivity of polyclonal antibodies to silver catfish IgM-like Ig was investigated using a dot blot assay and whole serum from twelve fish species (Fig.4A). A strong cross-reactivity was observed with serum from 4 different species (Hypostomus albopunctatus, Prochilodus lineatus, Hypostomus regani and Hypostomus strigaticeps). A weaker cross-reactivity was observed with three fish species (Ictalurus punctatus, Pseudoplatystoma corruscans and Salminus brazilienses) and faint or no cross-reactivity with the remaining 5 species (Piaractus mesopotamicus, Brycon amazonicus, Brycon hilarii, Leporinus friderici, Oreochromis niloticus). The putative IgM-like Ig from these fish species were slightly different in molecular size, mostly the $\mathrm{L}$ chain, as observed by SDS-PAGE and western blot analysis (Fig.4B,C). Cross reactivity and specificity of rabbit anti-silver catfish IgM was detected solely for the $\mathrm{H}$ chain.

\section{DISCUSSION}

The humoral branch of the acquired immune response is mediated mostly by Igs secreted by B lymphocytes in response to specific antigens (Magnadottir et al. 2005, Fillatreau et al. 2013). Igs have been isolated and characterized in several fish species and anti-Ig monoclonal and polyclonal antibodies are widely applied to study the humoral immune system and for developing immunoassays. In this study, an IgM-like Ig was purified from silver catfish serum and polyclonal antibodies against it were evaluated in different immunoassay aiming to further our understanding of silver catfish immune system and its response to inoculated antigens.

A molecular weight analysis of the proteins eluded from the affinity columns indicated the presence of two major proteins similar in size to the $\mathrm{H}$ and $\mathrm{L}$ chain of human IgM. The presumed molecular weight of silver catfish $\mathrm{H}(75 \mathrm{kDa})$ and $\mathrm{L}(28 \mathrm{kDa})$ chains are within the range reported for several teleost fish Igs (Grove et al. 2006b, Bag et al. 2009, Santos et al. 2009, Purcell et al. 2012). Additional proteins in the vicinity of the $75 \mathrm{kDa}$ major band were also observed in some aliquots eluted from the BSA-affinity column, or detected by western blot in the serum of several fish species used in this study. Evidence for the existence of distinct forms of H (Palenzuela et al. 1996, Watts et al. 2001, Jang et al. 2004, Suresh Babu et al. 2008) and L chain (Espelid \& Grøntvedt 2003, Ishikawa et al. 2004, Feng et al. 2009) within teleost fish has already been reported and our data indicates that this could also be true for silver catfish and the other fish evaluated here. However, slight differences in the molecular weight of a protein might be attributed to different pattern of glycosylation. Because carbohydrate moieties might account for up to $10 \%$ of the molecular weight of fish IgM-like (Magnadóttir et al. 2002, Cheng et al. 2006, Grove et al. 2006b, Mancia et al. 2007, Feng et al. 2009), the additional proteins bands observed in our study could be the result of differences in amino acid glycosylation of the same Ig protein.

The IgM-like Ig eluted from the immuno-affinity colu$\mathrm{mn}$ was used to immunize rabbits. To assure that the rabbit polyclonal antiserum was indeed directed towards a protein with Ig characteristics and that it could be used to evaluate fish humoral response, we tested their binding properties in a dot-blot targeting BSA. In this assay, rabbit polyclonal antibodies reacted specifically with serum from fish immunized with BSA, indicating that the protein isolated by affinity chromatography had indeed binding proper- 


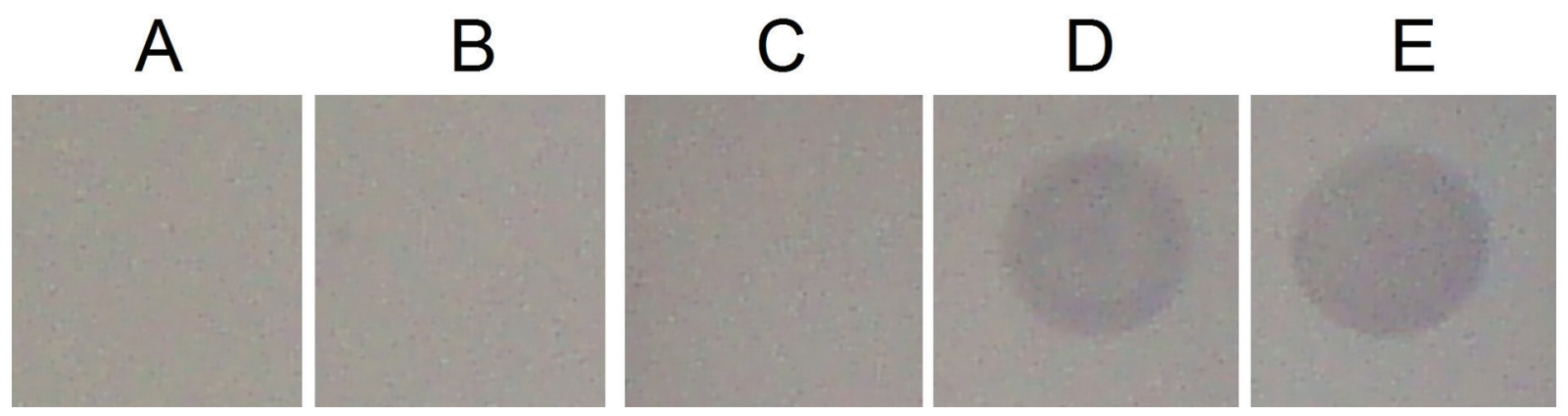

Fig.2. Dot blot analysis of silver catfish immunoglobulin binding properties and rabbit polyclonal antibody. Nitrocellulose membranes were spotted with $2 \mu \mathrm{l}$ of BSA $(4 \mathrm{mg} / \mathrm{ml})$ and reacted with silver catfish serum, rabbit polyclonal antibody to silver catfish IgM-like and goat anti-rabbit peroxidase conjugated, as indicated for each lane. (A) Fish serum was omitted and membranes were incubated with rabbit polyclonal and goat anti-rabbit conjugate; (B) rabbit polyclonal antibody was omitted and membranes were incubated with fish anti-BSA serum and goat anti-rabbit conjugate; (C) membranes were incubated with serum from fish prior to immunization with BSA followed by rabbit polyclonal and goat anti-rabbit conjugate; (D,E) membranes were incubated with serum from fish immunized with BSA followed by rabbit polyclonal and goat anti-rabbit conjugate.

ties and that rabbit polyclonal antibodies should be useful for developing immunoassay. Next, the cross-reactivity of rabbit polyclonal antibodies to serum Ig from several fish species was investigated using dot-blot and western blot. We found that rabbit polyclonal antibodies to silver catfish IgM-like cross-reacted with serum Ig from several other Siluriformes fish, namely I. punctatus, Pseudoplatystoma corruscans, Hypostomus albopunctatus, Hypostomus regain, and Hypostomus strigaticeps and with serum Ig from a Characiformes fish (Prochilodus lineatus). A weaker cross-reactivity was also observed with Igs from three Characiformes fish (Piaractus mesopotamicus, Salminus brazilienses and Leporinus friderici). No cross-reactivity was detected with Igs from the other fish species analyzed (Brycon amazonicus, Brycon hilarii, Oreochromis niloticus). Interestingly, Western blot analysis revealed a higher degree or cross-reactivity compared to dot-blot, and indicated that cross-reactivity was targeted solely to the $\mathrm{H}$ chain. The most pronounced contrast between dot-blot and western blot was observed comparing the reactivity of the polyclonal antibody to Brycon amazonicus; for this species, no cross-reactivity was observed with the native protein (dot blot) compared to a significant cross-reactivity following denaturing and western blot analysis. Ig $\mathrm{H}$ chain contains variable regions that interact with antigen and are exposed on the native protein, whereas constant regions might contain shared epitopes across different species (Miyadai et al. 2004, Rathore et al. 2008, Bag et al. 2009, Santos et al. 2009). Because polyclonal antibodies were directed toward the native silver catfish Ig, a less pronounced cross-reactivity was observed by dot-blot. However, the denaturing process, required to analyze proteins by SDS-PAGE might have exposed hidden Ig epitopes present mostly in the constant region that are shared by a larger number of fish, even within different order, resulting in a higher degree of cross-reactivity following denaturing. In contrast, polyclonal antibody reacted weakly to silver catfish $\mathrm{L}$ chain, and no cross-reactivity was observed with the L chain from fish species analyzed here, suggesting that the primary structures of $\mathrm{L}$ chains are less conserved amongst fish.

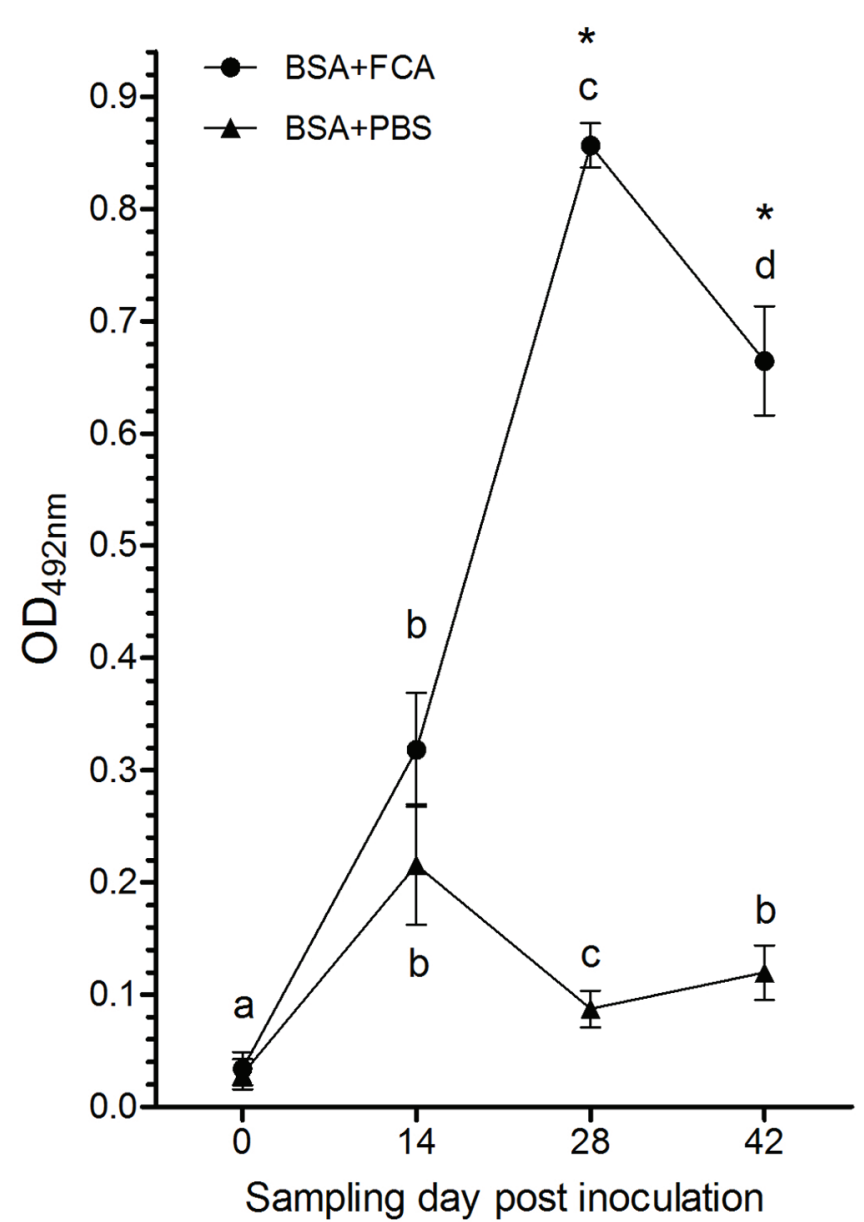

Fig.3. Indirect ELISA to detect antibodies in silver catfish immunized with BSA. Serum was collected from silver catfish prior to or at 14,28 and 42 days post-immunizations with BSA $(200 \mu \mathrm{g} /$ fish) adjuvanted with FCA or mixed to PBS. Each point represents the mean \pm SEM $(n=15)$. One-way ANOVA and Bonferroni's posttest was used to compare the data. Significant difference $(\mathrm{p}<0.001)$ between groups on the same day of sampling is indicated by asterisks. Difference $(\mathrm{p}<0.05)$ on antibody titers within the same group is indicated by letters. 


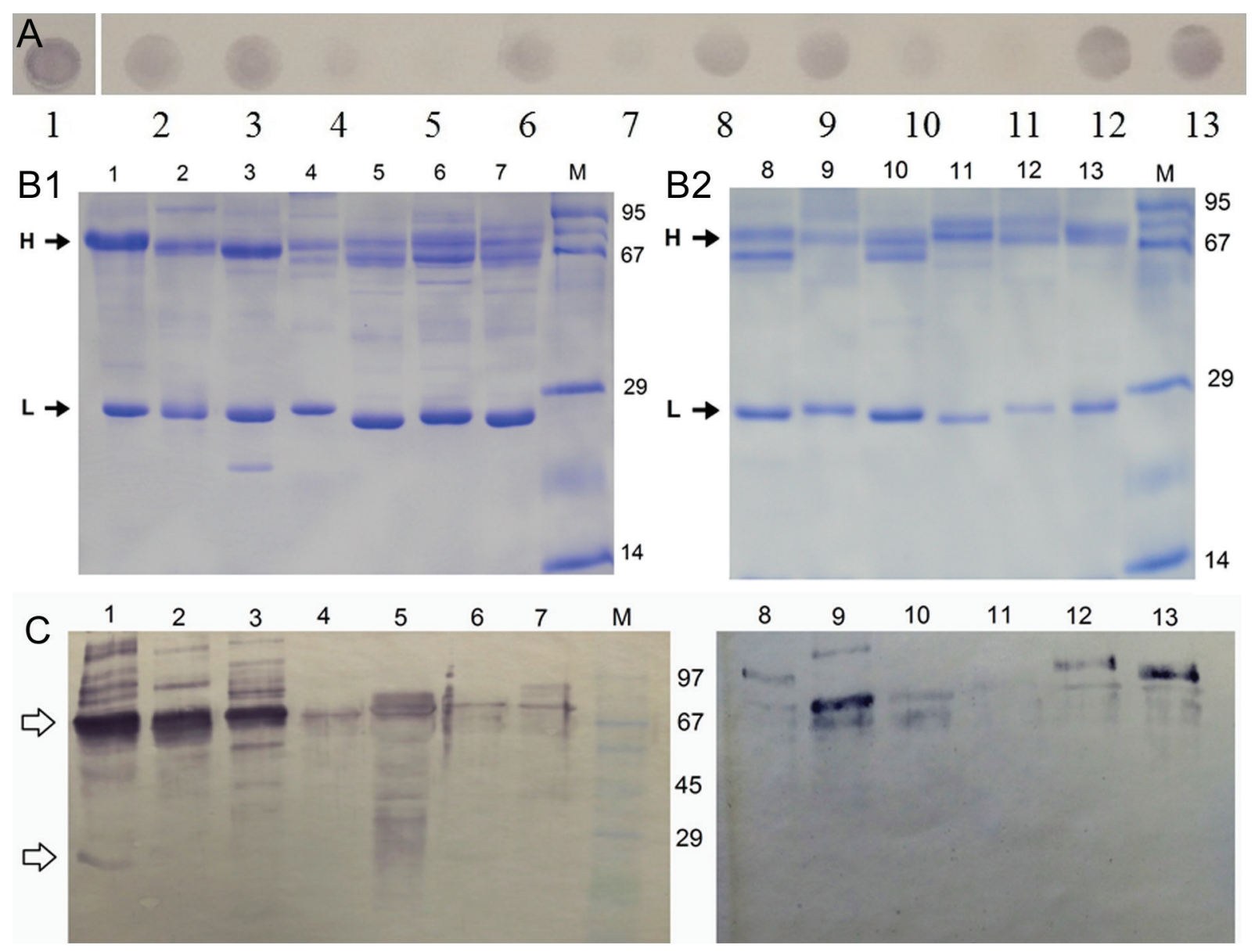

Fig.4. Cross-reactivity of rabbit polyclonal antibodies to silver catfish IgM with immunoglobulins from other Siluriformes and Characiformes fish. (A) Fish serum was spotted onto nitrocellulose membranes and incubated with rabbit polyclonal antibody to silver catfish IgM-like followed by goat anti-rabbit conjugate. (B) Denaturing SDS-PAGE analysis of fish serum indicating the putative location of immunoglobulin $\mathrm{H}$ and L chains. (C) Western blot analysis of serum fish detected using rabbit polyclonal antibody to silver catfish IgM-like and goat anti-rabbit conjugate. In all panels the serum analyzed were: 1: Rhamdia quelen (silver catfish); 2: Ictalurus punctatus (Catfish); 3: Pseudoplatystoma corruscans (Pintado); 4: Piaractus mesopotamicus (Pacu); 5: Brycon amazonicus (Matrinxâ); 6: Salminus brazilienses (Dourado); 7: Brycon hilarii (Piraputanga); 8: Hypostomus albopunctatus (Cascudo verdinho); 9: Prochilodus lineatus (Curimbatá); 10: Leporinus friderici (Piau); 11: Oreochromis niloticus (Tilápia); 12: Hypostomus regani (Cascudo pintado); $13:$ Hypostomus strigaticeps (Cascudo chato).

Finally, the usefulness of rabbit polyclonal antibodies to silver catfish IgM like was demonstrated by indirect ELISA. For this, serum from fish immunized with BSA (mixed to PBS or adjuvanted with FCA) had the Ig titer evaluated prior to and after immunization. There was no difference on anti-BSA antibody levels at 14 days post immunization. However, fish immunized with BSA+FCA had a sharp increase on anti-BSA antibodies titer determined at 28 days post immunization followed by a discrete but significant reduction by 42 days. In contrast, a sharp and significant reduction in anti-BSA antibodies titers was observed at 28 days in fish immunized with BSA mixed with PBS, strengthening that in fish adjuvants are fundamental to induce antibodies to soluble antigens. Knowing the kinetics and timing of antibody response to inoculated antigen is central to vaccine development and vaccination strategies. In general, the antibody response to inoculated antigens occurs within few days and reaches maximum levels 4 to 5 weeks following priming, as observed here, and also reported for turbot (Scophthalmus maximus) inoculated with different combinations of adjuvants and bacterial antigens (Zheng et al. 2012).

In conclusion, this is the first study describing the isolation of and IgM-like Ig from an indigenous Brazilian fish species and its use to produce polyclonal anti-Ig antibodies for the development of immunoassays. In addition, polyclonal antibodies to silver catfish IgM-like were useful to indicate the existence of common epitopes in several economically important fish species commonly found in South American rivers and lakes and should be likewise used to investigate the humoral immune response in these species.

Acknowledgements.- This study was funded by Conselho Nacional de Desenvolvimento Científico e Tecnológico (CNPq), Brazil, grant 476317/2012-6, and from the Secretaria de Desenvolvimento Econômico, Ciência e Tecnologia (SDECT, grant \#481-2500/13-2). CAPES provided a Master fellowship to Raíssa Canova (01589073029). Undergraduate fellowship was granted to Cristian 0. Nied (CNPq n. 125852/2013-4) and to Márcia Bortoluzzi (Probic/FAPERGS). Sabrina Ribeiro de Almeida (FZEA-USP) kindly provided fish serum samples for analysis. 


\section{REFERENCES}

Bag M.R., Makesh M., Rajendran K.V. \& Mukherjee S.C. 2009. Characterization of IgM of Indian major carps and their cross-reactivity with anti-fish IgM antibodies. Fish Shellfish Immunol. 26:275-278.

Beelen R., Boyd B., Garavello J.C., Pavanelli G.C. \& Ainsworth A.J. 2004. Generation, characterisation and applicability of a monoclonal antibody to hybrid surubim catfish Pseudoplatystoma corruscans (Agassiz) $\mathrm{x}$ Pseudoplatystoma fasciatum (Linnaeus) immunoglobulin. Comp. Clin. Pathol. 12:191-198.

Boardman T., Warner C., Ramirez-Gomez F., Matrisciano J. \& Bromage E. 2012. Characterization of an anti-rainbow trout (Oncorhynchus mykiss) CD3ع monoclonal antibody. Vet. Immunol. Immunopathol. 145:511-515.

Bradford M.M. 1976. A rapid and sensitive method for the quantitation of microgram quantities of protein utilizing the principle of protein-dye binding. Anal. Biochem. 72:248-254.

Cheng C.A., John J.A.C., Wu M.S., Lee C.Y., Lin C.H., Lin C.H. \& Chang C.Y. 2006. Characterization of serum immunoglobulin $M$ of grouper and cDNA cloning of its heavy chain. Vet. Immunol. Immunopathol. 109:255265.

Crosbie P.B. \& Nowak B. 2002. Production of polyclonal antisera against barramundi (Lates calcarifer Bloch) serum immunoglobulin derived from affinity columns containing mannan-binding protein or staphylococcal protein A. Aquaculture 211:49-63.

Da Silva L.B., Barcellos L.J.G., Quevedo R.M., De Souza S.M.G., Kessler A.D.M., Kreutz L.C., Ritter F., Finco J.A. \& Bedin A.C. 2008. Introduction of jundia Rhamdia quelen (Quoy \& Gaimard) and Nile tilapia Oreochromis niloticus (Linnaeus) increases the productivity of carp polyculture in southern Brazil. Aquac. Res. 39:542-551.

Espelid S. \& Grøntvedt R.N. 2003. Immunoglobulin VH families and light chain isotypes in the spotted wolffish (Anarhichas minor Olafsen). Fish Shellfish Immunol. 15:311-323.

Feng J., Guan R., Lin P. \& Guo S. 2009. Molecular cloning and characterization analysis of immunoglobulin $\mathrm{M}$ heavy chain gene in European eel (Anguilla anguilla). Vet. Immunol. Immunopathol. 127:144-147.

Fillatreau S., Six A., Magadan S., Castro R., Sunyer J.O. \& Boudinot P. 2013. The astonishing diversity of Ig classes and B cell repertoires in teleost fish. Front. Immunol. 4(28):1-14.

Grove S., Johansen R., Reitan L.J. \& Press C.M. 2006a. Immune- and enzyme histochemical characterisation of leukocyte populations within lymphoid and mucosal tissues of Atlantic halibut (Hippoglossus hippoglossus). Fish Shellfish Immunol. 20:693-708.

Grove S., Tryland M., Press C.M. \& Reitan L.J. 2006b. Serum immunoglobulin M in Atlantic halibut (Hippoglossus hippoglossus): characterisation of the molecule and its immunoreactivity. Fish Shellfish Immunol. 20:97112.

Hedfors I.A., Bakke H., Skjødt K. \& Grimholt U. 2012. Antibodies recognizing both IgM isotypes in Atlantic salmon. Fish Shellfish Immunol. 33:1199-1206.

Ishikawa J., Imai E., Moritomo T., Nakao M., Yano T. \& Tomana M. 2004. Characterisation of a fourth immunoglobulin light chain isotype in the common carp. Fish Shellfish Immunol. 16:369-379.

Iwasaki A. \& Medzhitov R. 2010. Regulation of adaptive immunity by the innate immune system. Science 327:291-5.

Jang H.N., Woo J.K., Cho Y.H., Kyong S.B. \& Choi S.H. 2004. Characterization of monoclonal antibodies against heavy and light chains of flounder $\mathrm{Pa}$ ralichthys olivaceus) immunoglobulin. J. Biochem. Mol. Biol. 37:314-319.

Li Q., Zhan W., Xing J. \& Sheng X. 2007. Production, characterisation and applicability of monoclonal antibodies to immunoglobulin of Japanese flounder (Paralichthys olivaceus). Fih Shellfish Immunol. 23:982-90.

Lim S.H., Ho H.T., Khader S.M.S. \& Kwang J. 2009. First report on the isolation of immunoglobulin M of guppy, Poecilia reticulata, for the production of polyclonal antibodies. Aquaculture 295:134-137.

Magnadóttir B. 2006. Innate immunity of fish (overview). Fish Shellfish Immunol. 20:137-151.
Magnadóttir B., Crispin M., Royle L., Colominas C., Harvey D.J., Dwek R.A. \& Rudd P.M. 2002. The carbohydrate moiety of serum IgM from Atlantic cod (Gadus morhua L.). Fish Shellfish Immunol. 12: 209-227.

Magnadottir B., Lange S., Gudmundsdottir S., Bøgwald J. \& Dalmo R. 2005. Ontogeny of humoral immune parameters in fish. Fish Shellfish Immunol. 19:429-439.

Mancia A., Romano T.A., Gefroh H.A., Chapman R.W., Middleton D.L., Warr G.W. \& Lundqvist M.L. 2007. Characterization of the immunoglobulin A heavy chain gene of the Atlantic bottlenose dolphin (Tursiops truncatus). Vet. Immunol. Immunopathol. 118:304-309.

Miyadai T., Ootani M., Tahara D., Aoki M. \& Saitoh K. 2004. Monoclonal antibodies recognising serum immunoglobulins and surface immunoglobulin-positive cells of puffer fish, torafugu (Takifugu rubripes). Fish Shellfish Immunol. 17:211-222.

Palenzuela O., Sitjá-Bobadilla A. \& Álvarez-Pellitero P. 1996. Isolation and partial characterization of serum immunoglobulins from sea bass ( $\mathrm{Di}$ centrarchus labrax L.) and gilthead sea bream (Sparus aurata L.). Fish Shellfish Immunol. 6:81-94.

Purcell M.K., Bromage E.S., Silva J., Hansen J.D., Badil S.M., Woodson J.C. \& Hershberger P.K. 2012. Production and characterization of monoclonal antibodies to IgM of Pacific herring (Clupea pallasii). Fish Shellfish Immunol. 33:552-558.

Rathore G., Kumar G., Sood N., Kapoor D. \& Lakra W.S. 2008. Development of monoclonal antibodies to rohu [Labeo rohita] immunoglobulins for use in immunoassays. Fish Shellfish Immunol. 25:761-774.

Salinas I., Zhang Y.A. \& Sunyer J.O. 2011. Mucosal immunoglobulins and B cells of teleost fish. Dev. Comp. Immunol. 35:1346-1365.

Santos M.D., Saito-Taki T., Takano T., Kondo H., Hirono I. \& Aoki T. 2009. Characterization of polyclonal antibodies against Japanese flounder IgM derived from recombinant IgM constant region proteins. Fish Shellfish Immunol. 27:374-378.

Schulz U.H. \& Leuchtenberger C. 2006. Activity patterns of South American silver catfish (Rhamdia quelen). Braz. J. Biol. 66:565-574.

Secombes C. 2008. Will advances in fish immunology change vaccination strategies? Fish Shellfish Immunol. 25:409-416.

Sood N., Chaudhary D.K., Rathore G., Singh A. \& Lakra W.S. 2011. Monoclonal antibodies to snakehead, Channa striata immunoglobulins: Detection and quantification of immunoglobulin-positive cells in blood and lymphoid organs. Fish Shellfish Immunol. 30:569-575.

Sunyer J.0. 2013. Fishing for mammalian paradigms in the teleost immune system. Nat. Immunol. 14:320-26.

Suresh Babu P.P., Shankar K.M., Honnananda B.R., Vijaya Kumara Swamy H.V., Prasanna Shama K., Suryanarayana V.V.S. \& Dechamma H.J. 2008. Isolation and characterization of immunoglobulin of the Indian major carp, rohu [Labeo rohita (Ham.)]. Fish Shellfish Immunol. 24:779-783.

Swennes A.G., Findly R.C. \& Dickerson H.W. 2007. Cross-immunity and antibody responses to different immobilisation serotypes of Ichthyophthirius multifiliis. Fish Shellfish Immunol. 22:589-597.

Tian J., Sun B., Luo Y., Zhang Y. \& Nie P. 2009. Distribution of IgM, IgD and IgZ in mandarin fish, Siniperca chuatsi lymphoid tissues and their transcriptional changes after Flavobacterium columnare stimulation. Aquaculture 288:14-21.

Watts M., Munday B.L. \& Burke C.M. 2001. Isolation and partial characterisation of immunoglobulin from southern bluefin tuna Thunnus maccoyii Castelnau. Fish Shellfish Immunol. 11:491-503.

Zhang Y.A., Salinas I., Li J., Parra D., Bjork S., Xu Z., LaPatra S.E., Bartholomew J. \& Sunyer J.0. 2010. IgT, a primitive immunoglobulin class specialized in mucosal immunity. Nat. Immunol. 11:827-835.

Zhang Y.A., Salinas I. \& Sunyer J.O. 2011. Recent findings on the structure and function of teleost IgT. Fish Shellfish Immunol. 31:627-634.

Zheng Z., Yingeng W., Qingyin W., Nannan D., Meijie L., Jiangbo Q., Bin L. \& Lan W. 2012. Study on the immune enhancement of different immunoadjuvants used in the pentavalent vaccine for turbots. Fish Shellfish Immunol. 32:391-5. 